\title{
Cystic Duct Stone
}

National Cancer Institute

\section{Source}

National Cancer Institute. Cystic Duct Stone. NCI Thesaurus. Code C35333.

A concretion in the cystic duct. 